\title{
The Influence of Motivation, Academic Supervision, and Work Discipline on Teachers' Performance at SMA Nahdhotul Islam Sri Tiga
}

\author{
Firmansyah $^{1 *}$, Happy Fitria ${ }^{1}$, Alfroki Martha ${ }^{1}$ \\ ${ }^{1}$ Universitas PGRI Palembang \\ *Corresponding author. Email: Awiee1986.fp@gmail.com
}

\begin{abstract}
This study aims to determine the effect of motivation, academic supervision, and work discipline on the teachers' performance at SMA Nahdhotul Islam Sri Tiga. The location of this research was carried out at SMA Nahdhotul Islam Sri Tiga. The type of research is quantitative research. The population in this study were all teachers of SMA Nahdhotul Islam Sri Tiga. The sample in this study is the total of all teachers at SMA Nahdhotul Islam Sri Tiga totaling 53 teachers. Data collection techniques were questionnaires, documentation, and observation. The data analysis technique used quantitative descriptive analysis techniques and multiple regression. The results of this study proved that 1) there is a significant influence between motivation on the teachers' performance at SMA Nahdhotul Islam Sri Tiga; 2) there is a significant influence between academic supervision on the teachers' performance at SMA Nahdhotul Islam Sri Tiga; 3) there is a significant influence between work discipline on teachers performance at SMA Nahdhotul Islam Sri Tiga; and 4) there is a significant influence between motivation, academic supervision, and work discipline together on teachers performance at SMA Nahdhotul Islam Sri Tiga. So, it can be concluded that the teachers' performance at SMA Nahdhotul Islam Sri Tiga are influenced by motivation, academic supervision, and discipline.
\end{abstract}

Keywords: Motivation, Academic Supervision, Work Discipline, Teacher Performance

\section{INTRODUCTION}

Law Number 20 of 2003 in the National Education System states that National Education serves to develop capabilities and shape dignified character and civilization to educate the nation's life, to develop students' potential to become faithful human beings. " [1]. This quote demonstrates that education is a strong and authoritative social institution that empowers all Indonesian citizens to develop into qualified human beings capable of responding to the challenges of ever-changing times.

Article 31 of the Republic of Indonesia's 1945 Constitution states that: (1) every citizen has the right to education; (2) the government must seek and administer a legalized national education system; (3) every citizen is required to attend basic education, which the government must fund; (4) the government shall endeavor and implement a national education system that fosters faith and devotion, as well as noble morals, within the framework of the nation's intellectual life, as prescribed by law; and (5) The state prioritizes the education budget of at least $20 \%$ (twenty percent) of the State Revenue and Expenditure Budget (APBN) and the Regional Revenue and Expenditure Budget (APBD) to meet the needs of the provision of national education.
The provision of quality education produces the quality of Indonesian people envisioned in Law Number 20 of 2003 and the 1945 Constitution. As a result, teachers serve a critical strategic function, role, and position. Teachers' positions as professionals have a vision for the realization of learning implementation under the principles of professionalism to fulfill the same rights for every citizen in obtaining a quality education. The position of teacher as a professional has the following mission to carry out the objectives of this law:

1. Enhance the teacher's dignity

2. Ensure teachers' rights and obligations

3. Enhance teacher competence

4. Advancing teachers' professions and careers

5. Enhance the learning experience

6. Raise the standard of national education

7. Closing the educational quality gap between regions

8. Improve the quality of education services.

9. Closing the availability gap between regions in terms of number, quality, academic qualifications, and competencies.

Under this function, the position of teachers as professionals aims to implement the national education system and realize national education's 
goals, namely the development of students' potential to become human beings who believe and fear God Almighty, have a noble character, are healthy, knowledgeable, competent, creative, be independent and become democratic and responsible citizens. To be able to realize these national education goals, optimal teacher performance is needed.

The educational system's framework, such as educational output, is influenced by factors other than the teacher. Many variations influence and determine student learning outcomes, such as the applicable curriculum, the students themselves, facilities and facilities such as the physical form of buildings, study rooms, laboratories, libraries, and other comfortable and conducive supports, learning processes, and evaluation systems. However, if returned to the position of being a professional teacher, teacher management must within a certain extent be able to anticipate the weaknesses and shortcomings of these variables.

For example, if learning facilities are limited, teacher creativity in designing and utilizing simple instructional media is needed. Low student motivation to learn, teachers are required to stimulate students with various learning approaches. That is, in the learning management function, teachers are required to develop various variations, creativity, and learning innovations to adapt to the environmental conditions and students' learning.

This demand will be realized if the teacher has some basic requirements. First, the knowledge and experience of teachers as professionals is one of the keys to success, how to manage the learning process so that all students can be active physically, mentally, socially, and emotionally so that the learning process is active, learning outcomes are not only students know, but also can do something functional. Second, teachers are required to have high motivation, enthusiasm, and responsibility to carry out their duties.

The good performance of the teachers of SMA Nahdhotul Islam Sri Tiga is expected to be able to improve good learning outcomes for the future, considering that at present the government's attention to education is very large, namely by launching the 9 Year Compulsory Education Program, so that SMA Nahdhotul Islam Sri Tiga also must improve the quality of education through improving teacher performance.

The success of SMA Nahdhotul Islam Sri Tiga to support and succeed the Government Program to complete the 9 Year Compulsory Education, to form every independent citizen, has a personality with the provision of science and technology as well as faith and piety towards God Almighty can only be achieved if supported by sources human resources who are professional and can obey the law, are rational, innovative, have high integrity, and uphold ethics, it is necessary to take the following actions to improve the ability of teachers by providing education and training, fostering teachers, and making extension programs for teachers who are well planned.

Teacher training, secondary school (S-2), KKG, seminars, workshops, discussions, and other activities can be carried out to improve teacher skills and guidance. The implementation of teacher quality training will not be separated from the enhancement of teacher competence and must adhere to the teacher standardization system in each type and level of school education. The goal of developing teacher competency standards is to determine a measure of a teacher's ability to master knowledge and skills necessary for professional planning and management of the learning process in schools [2].

Teachers' performance is influenced by many factors, i.e. improvement in the teachers' quality of working, ranking/position of teachers, increasing salaries, number and composition of teachers based on workload. Those can also happen to the Sri Tiga Nahdhotul Islam High School teacher. The improvement of the teacher's performance at SMA Nahdhotul Islam Sri Tiga is very dependent on the human resources available at the institution, for this reason, SMA Nahdhotul Islam Sri Tiga started to improve management in every part of the organization.

Furthermore, in addition to developing Academic Supervision activities, there are individual psychological characteristics that play a critical role in improving teacher performance, specifically the problem of work discipline. According to Masaong, the purpose of academic supervision is to improve the learning and teaching process by guiding teachers [3]. Teachers with high work discipline are always motivated to work hard to achieve this because they have good work control and do not require strict supervision to achieve the predetermined level of work quality.

There are some studies had been done by previous researchers, i.e. Khasanah, et.al.; Setyaningsih; Santos, et.al.; and Linda, et.al., those studies proved that principal leadership, teacher work discipline, and teacher work motivation all have a partial and simultaneous impact on teacher performance [4]-[7]. The teachers' performance is defined as their ability and success in carrying out teaching tasks, and must successfully carry out his or her teaching duties [8]-[9]. Teachers perfomance is also a motivation for Teacher'superformanceording to Kartini and Kristiawan, the teacher's teaching spirit influences the students' ability [10]. Teachers with high work motivation will do more than just routine teaching tasks, but also increased school productivity.

Considering the current conditions at SMA Nahdhotul Islam Sri Tiga, teacher work discipline must always be developed optimally by utilizing working time or service hours, to perform tasks effectively as well as working mechanisms and 
procedures concerning the implementation of improvement and development of teacher performance by the plans and targets that have been set. SMA Nahdhotul Islam Sri Tiga must develop an effective and consistent academic supervision activity to encourage the teachers' work discipline that will also increase the quality of a school.

\section{METHODS}

This study used a quantitative approach. This study's population consisted of 53 teachers from SMA Nahdhotul Islam Sri Tiga in Banyuasin Regency, South Sumatra. In this study, saturated sampling was used, which is a sampling technique in which all members of the population are used as samples. Questionnaires, documentation, and observation were used to collect data. In this study, statistical analysis and inferential statistical analysis were used to analyze the data. Descriptive statistical analysis and instrument item analysis are examples of statistical analysis. Descriptive statistics are used to obtain a high-level overview of research data or responses to questionnaires distributed to respondents. This descriptive statistic describes the researcher's data's average, median, value range mode, maximum value, minimum value, standard deviation, and variance.

\section{RESULTS AND DISCUSSION}

The following tables are the basic statistical analysis of normality and homogeneity data:

Table 1. Normality Test

\begin{tabular}{|c|c|c|c|c|c|}
\hline \multicolumn{6}{|c|}{ One-Sample Kolmogorov-Smirnov Test } \\
\hline & & $\begin{array}{l}\text { Teacher'Perf } \\
\text { ormance (Y) }\end{array}$ & $\begin{array}{c}\text { Motivatio } \\
\mathrm{n}\left(\mathrm{X}_{1}\right)\end{array}$ & $\begin{array}{c}\text { Academic } \\
\text { Supervision } \\
\left(\mathrm{X}_{2}\right)\end{array}$ & $\begin{array}{c}\text { Discipline } \\
\left(\mathrm{X}_{3}\right)\end{array}$ \\
\hline \multicolumn{2}{|l|}{$\mathrm{N}$} & 53 & 53 & 53 & 53 \\
\hline \multirow{5}{*}{$\begin{array}{l}\text { Normal } \\
\text { Parame } \\
\text { ters }{ }^{a, b}\end{array}$} & Mean & 70.8113 & 73.6604 & 71.1698 & 70.6981 \\
\hline & $\begin{array}{l}\text { Std. } \\
\text { Deviation }\end{array}$ & 5.20006 & 6.71377 & 5.17663 & 5.44760 \\
\hline & Absolute & .156 & .195 & .149 & 0.102 \\
\hline & Positive & .081 & .195 & .079 & 0.102 \\
\hline & Negative & -.156 & -.157 & -.074 & -.095 \\
\hline \multicolumn{2}{|c|}{$\begin{array}{l}\text { Kolmogorove- } \\
\text { Smirnov Z }\end{array}$} & 1.138 & 1.416 & 1.082 & .746 \\
\hline \multicolumn{2}{|c|}{$\begin{array}{l}\text { Asymp. Sig. (2- } \\
\text { tailed) }\end{array}$} & .150 & .136 & 192 & .635 \\
\hline
\end{tabular}

a. Test distribution is Normal.

Based on Table 1, Asymp. Sig (2-tailed) value is more than $\alpha(0,05)$, which means that the data were normally distributed. Then, the homogeneity test can be seen as follow:
Table 2. Homogeneity Test

\begin{tabular}{|l|r|r|r|r|}
\hline & $\begin{array}{c}\text { Teacher'Perf } \\
\text { ormance (Y) }\end{array}$ & $\begin{array}{c}\text { Motivation } \\
\left(\mathrm{X}_{1}\right)\end{array}$ & $\begin{array}{c}\text { Academic } \\
\text { Supervision } \\
\left(\mathrm{X}_{2}\right)\end{array}$ & $\begin{array}{c}\text { Discipline } \\
\left(\mathrm{X}_{3}\right)\end{array}$ \\
\hline Chi-Square & $31.398^{\mathrm{a}}$ & $53.981^{\mathrm{b}}$ & $45.591^{\mathrm{c}}$ & $22.679^{\mathrm{a}}$ \\
df & 20 & 17 & 19 & 20 \\
Asymp. Sig. & .003 & .000 & .001 & .005 \\
\hline
\end{tabular}

a. 21 cells $(100,0 \%)$ have expected frequencies less than 5 . The minimum expected cell frequency is 2,5

b. 18 cells $(100,0 \%)$ have expected frequencies less than 5. The minimum expected cell frequency is 2,9

c. 21 cells $(100,00 \%)$ have expected frequencies less than 5. The minimum expected cell frequency is 2,7

Table 2 shows that the data is not homogeneous. It can be seen from the $s i g$ value $<\alpha(0.05)$. Then, the following tables are linearity test for each variable:

Table 3. Linearity Test between Motivation, Academic Supervision, Work Discipline on Teachers Performance

\begin{tabular}{|c|c|c|c|}
\hline & & & Sig. \\
\hline $\begin{array}{l}\text { Teacher's } \\
\text { Performance * } \\
\text { Motivation }\end{array}$ & $\begin{array}{l}\text { Between Groups } \\
\text { Within Groups }\end{array}$ & $\begin{array}{l}\text { (Combined) } \\
\text { Linearity } \\
\text { Deviation from } \\
\text { Linearity }\end{array}$ & $\begin{array}{l}.000 \\
.000 \\
.004\end{array}$ \\
\hline $\begin{array}{l}\text { Teacher's } \\
\text { Performance * } \\
\text { Academic } \\
\text { Supervision }\end{array}$ & $\begin{array}{l}\text { Between } \\
\text { Groups } \\
\text { Within Groups }\end{array}$ & $\begin{array}{l}\text { (Combined) } \\
\text { Linearity } \\
\text { Deviation from } \\
\text { Linearity }\end{array}$ & $\begin{array}{l}.000 \\
.000 \\
.000\end{array}$ \\
\hline $\begin{array}{l}\text { Teacher's Performance } \\
* \text { Work Discipline }\end{array}$ & $\begin{array}{l}\text { Between } \\
\text { Groups } \\
\text { Within Groups }\end{array}$ & $\begin{array}{l}\text { (Combined) } \\
\text { Linearity } \\
\text { Deviation from } \\
\text { Linearity }\end{array}$ & $\begin{array}{l}.000 \\
.000 \\
.002\end{array}$ \\
\hline
\end{tabular}

Table 3 shows that the sig value is $0,000<\alpha$ (0.05), which means that the data of teachers' performance, motivation, academic supervision, and work discipline were linear. Then, the following tables are correlational for each variable:

Table 4. Test Multicollinearity

Coefficients

\begin{tabular}{|c|c|c|}
\hline \multirow[b]{2}{*}{ Model } & \multicolumn{2}{|c|}{ Collinearity Statistics } \\
\hline & Tolerance & VIF \\
\hline $1 \quad$ (Constant) & & \\
\hline Motivation & .152 & 6.593 \\
\hline Academic Supervision & .194 & 5.166 \\
\hline Working Discipline & .203 & 4.925 \\
\hline
\end{tabular}

a. Dependent Variable: Teacher's Performance 
Table 4 shows that each variable has a tolerance value greater than 0.10 and a VIF value greater than10.00, indicating that there is no multicollinearity between the independent variables.

The following table is the result of autocorrelation among variables

Table 5. Autocorrelation Test Result

\begin{tabular}{|c|c|c|c|c|c|}
\hline \multicolumn{6}{|c|}{ Model Summary } \\
\hline Model & $\mathrm{R}$ & R Square & $\begin{array}{l}\text { Adjusted } \\
\text { R Square }\end{array}$ & $\begin{array}{l}\text { Std. Error } \\
\text { of the } \\
\text { Estimate }\end{array}$ & $\begin{array}{l}\text { Durbin- } \\
\text { Watson }\end{array}$ \\
\hline 1 & $.941^{\mathrm{a}}$ & .886 & .874 & 2.213 & 1.263 \\
\hline $\begin{array}{ll}\text { a. } & \mathrm{P} \\
& \mathrm{V} \\
\text { b. } & \mathrm{T}\end{array}$ & $\begin{array}{l}\text { ctors: } \\
\text { Disci } \\
\text { hers Pe }\end{array}$ & $\begin{array}{l}\text { (Constant) } \\
\text { line } \\
\text { formance }\end{array}$ & Motivat & Academic & Supervision, \\
\hline
\end{tabular}

Based on Table 5, the value of Durbin-Watson is $1,263<\mathrm{dl}$ (4), which means that there is autocorrelation among variables.

Then, the following tables are the detail of the influence of independent variables on dependent variable partially and simultaneously.

Table 6. Contribution of Motivation $\left(\mathrm{X}_{1}\right)$ on Teachers Performance $(Y)$

\begin{tabular}{|l|c|c|c|c|}
\hline \multicolumn{5}{|c|}{ Model Summary } \\
\hline Model & $\mathrm{R}$ & $\begin{array}{c}\mathrm{R} \\
\text { Square }\end{array}$ & $\begin{array}{c}\text { Adjusted R } \\
\text { Square }\end{array}$ & $\begin{array}{c}\text { Std. Error of } \\
\text { the Estimate }\end{array}$ \\
\hline 1 & $.928^{\mathrm{a}}$ & .861 & .876 & 2.213 \\
\hline
\end{tabular}

a. Predictors: (Constant), Motivation

b. Teachers Performance

Based on Table 6, the value of $\mathrm{R}$ is 0.928 , and $\mathrm{R}$ Square is 0.861 . It means that motivation $\left(\mathrm{X}_{1}\right)$ gives contribution to the teachers' performance $(\mathrm{Y})=$ $86,1 \%$.

Table 7. Contribution of Academic Supervision $\left(\mathbf{X}_{2}\right)$ on Teachers Performance $(\mathbf{Y})$

\begin{tabular}{|c|c|c|c|c|}
\hline \multicolumn{5}{|c|}{ Model Summary } \\
\hline Model & $\mathrm{R}$ & $\begin{array}{c}\mathrm{R} \\
\text { Square } \\
\end{array}$ & $\begin{array}{c}\text { Adjusted R } \\
\text { Square }\end{array}$ & $\begin{array}{l}\text { Std. Error of } \\
\text { the Estimate }\end{array}$ \\
\hline 1 & $.894^{\mathrm{a}}$ & .799 & .794 & 2.856 \\
\hline $\begin{array}{l}\text { a. } \\
\text { b. }\end{array}$ & & & & \\
\hline
\end{tabular}

Based on Table 7, the value of $\mathrm{R}$ is 0.894 , and $\mathrm{R}$ Square is 0.799 . It means that academic supervision $\left(\mathrm{X}_{2}\right)$ gives contribution to the teachers' performance $(\mathrm{Y})=79,9 \%$.
Table 8. Contribution of Work Discipline $\left(\mathrm{X}_{3}\right)$ on Teachers Performance (Y)

\begin{tabular}{|l|c|r|r|r|}
\hline \multicolumn{5}{|c|}{ Model Summary } \\
\hline Model & R & R Square & $\begin{array}{c}\text { Adjusted R } \\
\text { Square }\end{array}$ & $\begin{array}{c}\text { Std. Error of } \\
\text { the Estimate }\end{array}$ \\
\hline 1 & $.856^{\mathrm{a}}$ & .733 & .726 & 3.292 \\
\hline & & & & \\
\hline $\begin{array}{l}\text { a. Predictors: (Constant), Work Discipline } \\
\text { b. Teachers Performance }\end{array}$
\end{tabular}

Based on Table 8 , the value of $\mathrm{R}$ is 0.856 , and $\mathrm{R}$ Square is 0.733 . It means that work discipline $\left(\mathrm{X}_{3}\right)$ gives contribution to the teachers' performance $(\mathrm{Y})=$ $73,3 \%$.

Table 9. Contribution of Motivation ( $\left.\mathrm{X}_{1}\right)$, Academic Supervision $\left(\mathbf{X}_{2}\right)$, Work Discipline $\left(\mathbf{X}_{3}\right)$ on Teachers Performance (Y)

\begin{tabular}{|l|c|r|r|r|}
\hline \multicolumn{5}{|c|}{ Model Summary } \\
\hline Model & R & R Square & $\begin{array}{c}\text { Adjusted R } \\
\text { Square }\end{array}$ & $\begin{array}{c}\text { Std. Error of } \\
\text { the Estimate }\end{array}$ \\
\hline 1 & $.941^{\mathrm{a}}$ & .886 & .876 & 2.213 \\
\hline & & & \\
\hline a. Predictors: (Constant), Motivation, Academic \\
bupervision, Work Discipline \\
Teachers Performance \\
b.
\end{tabular}

Based on Table 9, the value of $\mathrm{R}$ is 0.941 , and $\mathrm{R}$ Square is 0.876 . It means that motivation $\left(\mathrm{X}_{1}\right)$, academic supervision $\left(\mathrm{X}_{2}\right)$, work discipline $\left(\mathrm{X}_{3}\right)$ give contribution simultaneously to the teachers' performance $(\mathrm{Y})=87,6 \%$.

Then, to answer the hypothesis of the influence independent variables on the dependent variable can be seen in the following tables:

Table 10. The Influence of Motivation, Academic Supervision, Work Discipline on Teachers Performance Partially

\begin{tabular}{|c|c|c|c|c|c|}
\hline \multicolumn{6}{|c|}{ Coefficients $^{\text {a }}$} \\
\hline \multirow[b]{2}{*}{ Model } & \multicolumn{2}{|c|}{$\begin{array}{c}\text { Unstandardized } \\
\text { Coefficients }\end{array}$} & \multirow{2}{*}{$\begin{array}{c}\text { Standardi } \\
\text { zed } \\
\text { Coefficie } \\
\text { nts } \\
\text { Beta }\end{array}$} & \multirow[b]{2}{*}{ t. } & \multirow[b]{2}{*}{ Sig. } \\
\hline & B & Std. Error & & & \\
\hline (Constant) & 18.074 & 7.291 & & .761 & .000 \\
\hline Motivation & .052 & .061 & -.008 & -.098 & .019 \\
\hline Academic & .397 & .087 & .262 & 3.105 & .003 \\
\hline Supervision & & & & & \\
\hline Work Discipline & .134 & .082 & .696 & 7.604 & .000 \\
\hline
\end{tabular}

Dependent Variable: Teacher's Performance

This table shows that (1) There is a significant effect of motivation on the performance of the Sri Tiga Nahdhotul Islam High School Teacher. Based on the sig value, it can be seen that $0.019<\alpha(0.05)$ means the motivation variable has a partially significant effect on the performance variable; (2) There is a significant effect of supervision on the performance at the Sri Tiga Nahdhotul Islam High School Teacher. Based on the sig value, it can be seen 
that $0.003<\alpha(0.05)$ means the academic supervision variable has a partially significant effect on the performance variable; and (3) there is a significant effect of work discipline on the performance at the Sri Tiga Nahdhotul Islam High School Teacher Based on the sig value, it can be seen that $0,000<\alpha(0.05)$, means that work discipline variable has a partially significant effect on the performance variable. So, based on Table 10, Ho is rejected and Ha is accepted. Thus, there is a significant effect of independent variables on dependent variable partially.

Table 11. F-Test the Influence of Motivation, Academic Supervision, Work Discipline on Teachers Performance Simultaneously

\begin{tabular}{|c|c|c|c|c|c|c|}
\hline \multicolumn{7}{|c|}{ ANOVA $^{\mathrm{a}}$} \\
\hline \multicolumn{2}{|c|}{ Model } & $\begin{array}{l}\text { Sum of } \\
\text { Squares }\end{array}$ & $\mathrm{df}$ & $\begin{array}{l}\text { Mean } \\
\text { Square }\end{array}$ & $\mathrm{F}$ & Sig. \\
\hline \multirow[t]{3}{*}{1} & $\begin{array}{l}\text { Regressio } \\
\mathrm{n}\end{array}$ & 778.550 & 2 & 259.517 & 34,144 & $.000^{\mathrm{b}}$ \\
\hline & Residual & 372.431 & 49 & 7.601 & & \\
\hline & Total & 1150.981 & 52 & & & \\
\hline
\end{tabular}

b. Predictors: (Constant), Teaching Experience, Training

Based on Table 11, the sig value is $0.000<\alpha$ (0.005), which means that motivation, academic supervision, work discipline give effect simultaneously on teachers' performance at SMA Nahdhotul Islam Sri Tiga Teachers.

This research proved also the previous researches, ofw Khasanah et al., Setyaningsih et al., Santos et al., and Linda et alho found that teachers' performance is influence by some factors, i.e. leadership, work discipline, and motivation [4]-[7]. Individual psychological characteristics play an important role in improving teacher performance.

\section{CONCLUSION}

Motivation, academic supervision, work discipline have a significant influence on teacher's performance simultaneously at SMA Nahdhotul Islam Sri Tiga Teachers. The higher contribution of influence is from motivation. Work motivation influences teacher performance positively. So, the principal as a leader at school must always motivate the teachers. That's why supervision is very needed because it is one way of management control in the educational process. Also, to force teachers to become a discipline in doing their duties as an educator.

\section{REFERENCES}

[1] Soewondo, S. (2013). Human Resource Management. Bandung: Alfabeta
[2] Law of Republic of Indonesia No. 20 of 2003 concerning the National Education System

[3] Masaong, A. K. (2012). Supervisi Pembelajaran dan Pengembangan Kapasitas Guru: Memberdayakan Pengawas sebagai Gurunya Guru. Alfabeta.

[4] Khasanah, U., Kristiawan, M., Tobari. (2019). The Implementation of Principals' Academic Supervision in Improving Teachers' Professionalism in the State Primary Schools. International Journal Of Scientific \& Technology Research Volume 8, Issue 08, 1107-1115. https://www.ijstr.org/paperreferences.php?ref= IJSTR-0819-21239.

[5] Setyaningsih, T. T. (2020). Influence of School Leadership, Discipline, and Work Motivation Toward High School Teacher Performance. Harmoni Sosial: Jurnal Pendidikan IPS Volume 7, 43-56 No. http://journal.uny.ac.id/index.php/ hsjpi.

[6] Santos, R. D., Rusdarti, \& Mulyono, S.E. (2020). The Effect of Academic Supervision and Principal's Leadership on Teacher Performance through Work Motivation in SD Negeri Tasifeto Barat Belu District, East Nusa Tenggara. Jurnal Educational Management. Vol. 9, No. 1, 25-33, http://journal. unnes. ac.id/sju/ index.php/eduman

[7] Lindra., Rusdinal., \& Sabandi, A. (2020). The Effect of Academic Supervision and Achievement Motivation to the Teachers' Performance of Senior High School. International Journal of Progressive Sciences and Technologies (IJPSAT). Vol. 19 No. 1 February 2020, pp. 22-30. https://ijpsat.ijshtjournals.org/index.php/ijpsat/article/view/1556/ 845

[8] Hasibuan. (2014). Manajemen Sumber Daya Manusia. Bumi Aksara.

[9] Fitriani, C., Muniarti, A. R., \& Usman, N. (2017). Kompetensi profesional guru dalam pengelolaan pembelajaran di MTs Muhammadiyah Banda Aceh. Jurnal Administrasi Pendidikan, 5(2), 88-95. http://jurnal.unsyiah.ac.id/JAP/article/view/824 6

[10] Kartini, D., \& Kristiawan, M. (2019). Pengaruh tunjangan profesi dan motivasi kerja terhadap kinerja guru. Kelola: Jurnal Manajemen Pendidikan, 6(1), 25-33. Doi: https://doi.org/10. 24246/ j.jk. 2019.v6.i1.p25-33. 